\title{
THE PROCESSES ANALYSIS OF URBANIZATION, SPATIAL ARTICULATION, SOCIAL CHANGEAND SOCIAL CAPITAL DIFFERENCE IN THE DYNAMICS OF NEW TOWN DEVELOPMENTIN THE FRINGE AREA OF MAKASSAR CITY, INDONESIA

\author{
Batara Surya \\ University 45 of Makassar - Indonesia \\ Batara_surya1945@yahoo.co.id
}

\begin{abstract}
The study aims at analyzing process of urbanization and spatial articulation as the determinant of social change, and finding out social capital differences between migrant and local community in the dynamics of new city development in Metro Tanjung Bunga area. The findings show that spatial articulation in Metro Tanjung Bunga area was initiated by the development of new functions as a stimulating factor of urbanization and infiltrative and expansive migration to Metro Tanjung Bunga area. Spatial articulation causes coexistence of two kinds of mode of production in mastery of reproduction of space which is dominated by capitalist mode of production. It also has an effect of social change and social capital difference between migrant and local community. Occupational differentiation drives process of social interaction between local community and migrant in purpose to establish social relationship and social relations. Economically, the establishment is integrative for basic needs compliance and in effort to maintain existence of local community. Social change portrays differences of social capital, social order and life style between expansive migrant, infiltrative migrant and local community.
\end{abstract}

\section{Indexing terms/Keywords}

Urbanization, Spatial Articulation, Social Dynamics, Social Capital

\section{Academic Discipline And Sub-Disciplines}

Urbanand Regional Planning

\section{SQALITUBJECT CLASSIFICATION}

Social Capital

\section{TYPE (METHOD/APPROACH)}

ative study. Qualitative study

\section{Council for Innovative Research}

\section{Peer Review Research Publishing System}

Journal: Journal of Social Sciences Research

Vol .7, No.1

jssreditor.cir@gmail.com

www.jssronline.com 


\section{INTRODUCTION}

The dynamics of urban area concerns the presence of residential area in an unified urban residential area. Development of urban residential area and heterogeneous, modern, complex and multicultural society as well populous and dirty residential area are running two abreast. This phenomenon is so different from rural residential area. Socio-cultural life in society within one unified urban residential area is assessed based on social differentiation, social relationship pattern, social relation, social structure, social system that color a quality of the city (Ibrahim, 2005).

The development of city and urban area, especially major cities in Indonesia, is an inseparable effect of globalization and modernization which the two causal factor also results in urbanization, in addition to transportation and technological advance factors. Macro and micro social changes will contribute positively changes in society at macro level in urban area, especially in the dynamics of new town development taking place in the urban fringe area. Globalization and modernization occurred in the fringe area indicate that social change at micro level will contribute positively in the dynamics of society. This process is observable in the process of new town development along with its significant effect on social capital difference emerged in community level. Social capital as reference of social life basically is assessed based on social solidarity and social relationship.

Some spatial sociology studies conducted in the urban fringe area of Makassar City found that phenomenon of social segregation was initiated by the time when coexistence of capitalist mode of production and pre-capitalist mode of production ran simultaneously in mastery of reproduction of space dominated by capitalist mode of production. Eventually, social change occurs, and it is designated by social stratum sharpening economically in local community and it associates positively to social capital difference in the dynamics of social life in the fringe area of Makassar City.

Local cultural system study with new configuration in some aspects of urban social life in the fringe area of Makassar City concerns lifestyle of urban sub-culture, social disorganization, and anomie. The reality is relevant with theoretical conceptualization of Ibrahim (2005) that urbanization and technological advance has an effect on socio-cultural life, specifically for inter-individual interaction that changes social relationship pattern (Borja Jordi \& Castells Manuael, 1977).

The dynamic of development in Makassar City makes middle to low stratum group live in fringe area. Concurrently, this area also faces modernization in the name of new town development. This condition affects social dynamic of local community directly and indirectly.

Metro Tanjung Bunga area is determined as object of the study. It is administratively in Tanjung Merdeka Subdistrict, Tamalate District, Makassar City. Metro Tanjung Bunga area is inhabited by local community who takes natural resources as their source of life. Generally, local community's orientation to activity from year period of 1970s to the end of 1995 is farmer, fisherman and aquaculturist in a homogeneous and rural agrarian society. Administratively, the area is in the fringe area of Makassar City. Long ago, Makassar City was only accessible by fisherman's boat. Landline access was commenced since 2003 and it is marked by the presence of Metro Tanjung Bunga road. Consequently, transportation mobility increases. Distance from the midtown of Makassar to Metro Tanjung Bunga area is around $5 \mathrm{Km}$. It is accessible by public transportation or private vehicle at traveled distance of about 15-20 minutes. There are many choices of mode of transportation to access Metro Tanjung Bunga area.

Based on the registrar book, population density in 2000 was 1,226 people $/ \mathrm{km}^{2}$ and 28,902 people $/ \mathrm{km}^{2}$ in 2014 (Central Bureau of Statistics of Makassar, 2012). Therefore, recent population density in Metro Tanjung Bunga area is increasing at population growth of 2,403 people $/ \mathrm{km}^{2}$. Fairly high population growth in Metro Tanjung Bunga area indicates that spatial physical change has significantly happened. It is portrayed by the existing of new functions like large scale residential area, office complex, shopping center (mall), shopping complex, health and education facilities to support main function of the area as the center of business/commercial, recreation, office and services activities.

\section{RESEARCH METHOD}

This belongs to qualitative study. Qualitative study was introduced by John W. Creswell (1997) consisting of tradition of biography, phenomenology, grounded theory, ethnography, and case study. The study focuses mainly on the process of urbanization and spatial articulation which both are determined as determinant of social change and social capital difference in the development of Metro Tanjung Bunga area. Accordingly, applied research approach is case study. 


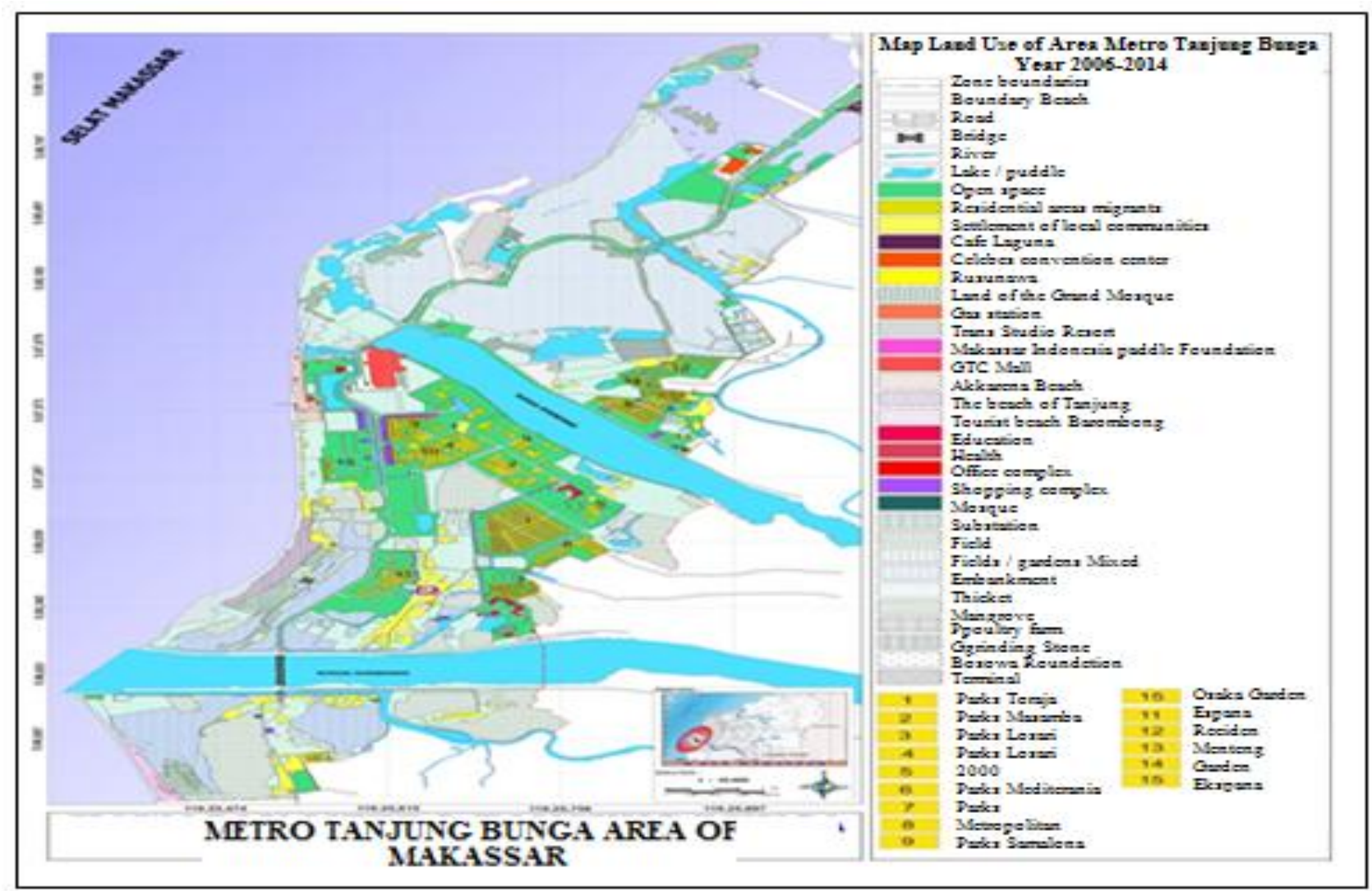

Fig 1. New Town Area in Metro Tanjung Bunga is Determined as the Object of the Study, 2014

Case study approach is chosen under some consideration:(a) that spatial physical change in Metro Tanjung Bunga is specific and revolutionary, and it is arranged in complexity.(b) the nature of the case has a very prominent pattern, consistency and sequence.(c) context of the case is new town area of Metro Tanjung Bunga is complex enough.(d) nature of the case aims at understanding background or an event that makes social change and social capital difference happen as the consequence of spatial articulation through a process of coexistence of capitalist mode of production and precapitalist mode of production. Based on the focus of the study, what will be constructed in the study is process of urbanization. It is considered that the process becomes the determinant of social change, process of social interaction and social capital difference between migrant and local community inhabiting Metro Tanjung Bunga area. Hence, the study aims at having a deep understanding of and interpretation of the way social change is faced by local community, and social capital difference established in development and expansion of the new town area of Metro Tanjung Bunga.

\section{Discussion}

Around 1930s, Metro Tanjung Bunga area, i.e. Tanjung Merdeka Sub-district, and Barombong Sub-district were one subdistrict. Authority at that time was entitled by head (sub-district then) led by Anrung Barombong. Initial formation of Bayang village was in relevance with trading activity due to the presence of seaport town of Sombaopu as the main trading town of Gowa Kingdom in mouth of Jeneberang river. In early of Independence Day (1945), Bayang and Barombong villages was set within a part of Limbung district jurisdiction, in administrative jurisdiction of Gowa Regency. The fact indicates that, initially, Tanjung Merdeka Sub-district (in Metro Tanjung Bunga area) was a part of Barombong Sub-district, and administratively, it is in the region of Gowa Regency.

\section{Urbanization, Spatial Articulation and Social Change}

The development of Makassar City, especially in the fringe area of Metro Tanjung Bunga, reflects phenomenon of "suburbanization" and socio-economic spatial functions change. Fact found in the field shows that commercial economic activity function established since 2003-2004 leads to global economy orientation. One of indications is the presence of Mall GTC and Theme Park Trans Studio as the biggest recreational facility in Eastern Indonesia Zone. The presence of commercial economic activity functions encourages socio-economic function movement. Presumably, a large scale residential area construction to Metro Tanjung Bunga area, then will weaken local economic linkage, especially economic capacity of surrounding cities. Development of Metro Tanjung Bunga which is dominated by the presence of centers of economic activity and large scale residential construction has an effect on the hight of transportation flow from midtown of Makassar City, i.e. movement from Gowa Regency and Takalar Regency including migrant mobility either infiltrative or expansive migrants. Paul Knox (in Soetomo, 2009) describes the process of urbanization as a process which is driven by economic change, and encouraged by human resources, natural resources and technology (human-made resources), and it has economic, social and physical output along with problems to be faced in urban development policy. 
Fig 2.Urbanization as a process, 1994, Paul. L. Knox (Soetomo, 2009: 43)

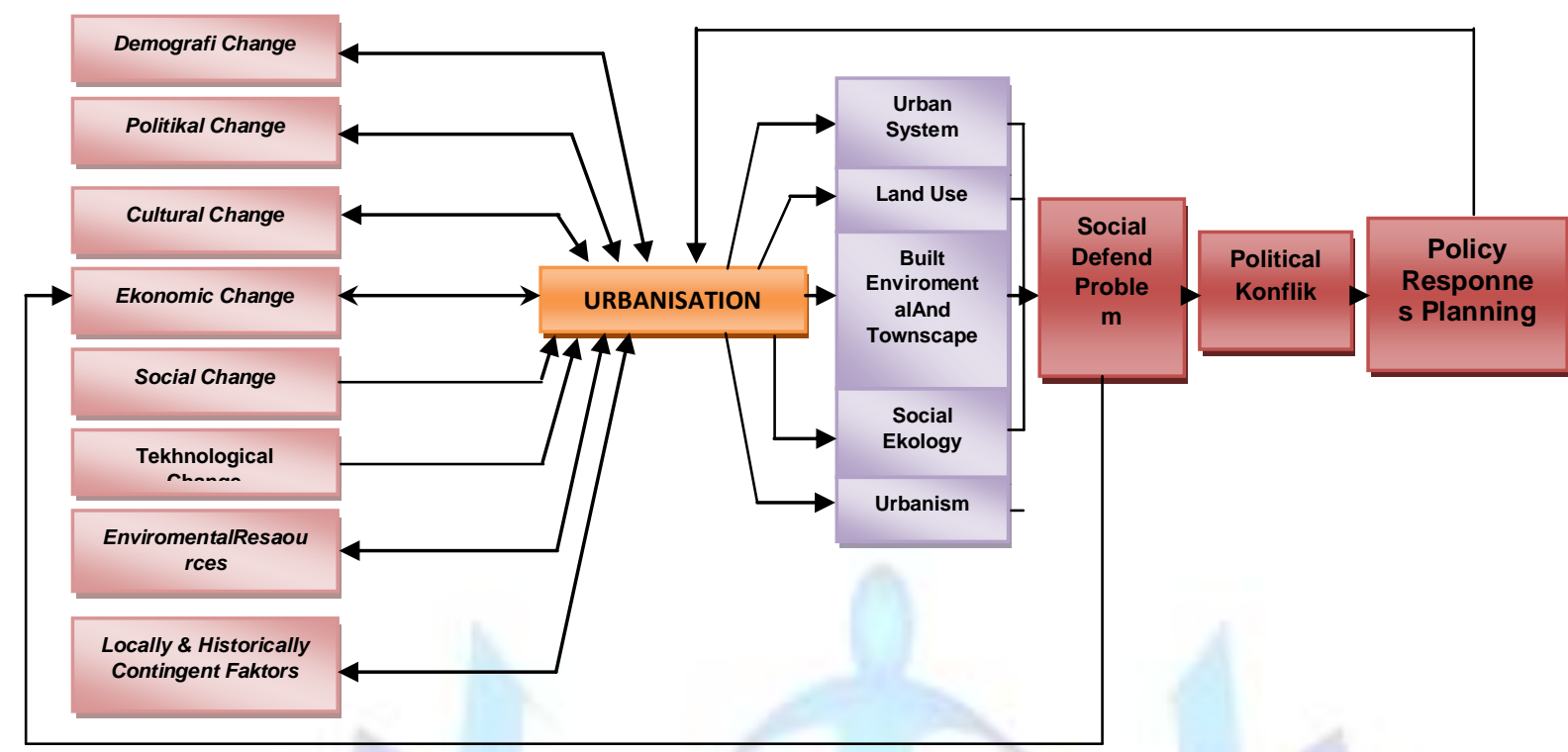

Figure 2. the diagram points out three emerging event groups. First, process of urbanization and economic factor that drives and leads to changes in all aspects: population, politic, culture, social, technology, natural resources and historical yield. Second, the yield of urbanization process directing internally toward the city changes morphological appearance of city, social interaction, land use and also creates various aspects in urban life (social, economic, politic, and culture). External process creates urban system in regional scope, either physical or non-physical aspect (social, economic, culture, politic, or region authority). Process of urbanization and the products are outcome of the development produced by all aspects of life and physical environment in various scales including residential environment, city, regional, national and international (Soetomo, 2009). Theoretical conceptualization of Soetomo is true and it is relevant with current process in Metro Tanjung Bunga area, Makassar City. Therefore, it can be concluded that urbanization occurred in Makassar City affects developmental dynamics in the fringe area of Metro Tanjung Bunga as a new town area. This condition is marked by a large scale residential construction as places of residence for groups of urbanism. Finally, the construction will be a driving force of social change in local community of Metro Tanjung Bunga area.

The dynamic of development in Metro Tanjung Bunga area, at the same time, encourages development of new social order and forms social surplus. When social surplus exists, it will create urban society and a town thereupon. The reality affirms theoretical conceptualization of Robert Potter (in Soetomo: 2009) that any phenomenon named as first city is born when process of development in the society accumulates and forms a power concentration of society and politic-social or economic organization. Consequently, it creates power and determines expansion of the region. Therefore, it can be concluded that social surplus in Metro Tanjung Bunga area relates to the presence of urbanism groups with their capital ownership, and creates power through dominance over mastery of reproduction of space in the new town of Metro Tanjung Bunga, Makassar City.

Urbanization as a process in the dynamic of new town development in Metro Tanjung Bunga area gives an overview that (1) the town is established by development of diverse society. This diversity, vertically or horizontally, is a natural process in formation of a town that assumable, the process of urbanization is an unlike social change over time. (2) At postindustrial revolution, town was established by various and diverse aspects. Social surplus creates social diversity horizontally (kind) and vertically (level/class). Therefore, it is assumed that process of urbanization in Metro Tanjung Bunga area as a new town is a process of town or urban community formation, and this process will always cause unequal distribution and disparity socially-economically. The reality is relevant with theoretical conceptualization of Santos (in Soetomo: 2009) that social change as a process of modernization is a different process faced by every member of society.

Motivating and attracting factors on why inhabitants and socio-economic activity functions move to fringe area is dominantly triggered by development of new activity centers whereas, it is impossible to develop the midtown more (Yunus, 2008). For 2003-2010, accellerated development in Metro Tanjung Bunga area has a significant effect on land use conversion. This process is marked by the presence many functions like economic/commercial, education, health, office, large scale residential area and other social activities backed up by transportation infrastructure. The process then increases accessibility in Metro Tanjung Bunga area either in the midtown of Makassar City or hinterland area, and it associates positively to spatial physical change that becomes determinant of social change in local community inhabiting the new town area of Metro Tanjung Bunga, Makassar City.

Harison, E. L. Huntington, S.P. (2006), in his book entitled The Production of Space emphasizes means of production to production of space. He observes focus shift from things in a space within the actual production itself. Frequently, space produces capitalist system and class structure in economic system. Accordingly, every revolutionary action shall focus on restructuring of space. Perspective of Lefebvre is directed to justification as follows: First, means of production to reproduction of space. Second, space is set in context of preferred social change. World is dominated, controlled, 
performed by the state, capitalist and bourgeois. Accordingly, if the concept is applied in the dynamic of new town development in Metro Tanjung Bunga, it portrays that space shift is driven by the presence of capitalist in new town development. On the other side, it triggers process of continuous spatial articulation through imbalance mastery of space; consequently, it becomes driving force of social change at micro level in local community.

Approach of articulation focusing on mode of production was initially closely related to French anthropologist-economist, Meillassoux, Terray, and Rey, then, it becomes new focus of "a new economyanthropology" in the world (Economy and Society and Critique of Anthropology). In the process of development, articulation approach is applied to declare a more expansive concrete research including imperialism, production of commodity in town, peasant, and undistributed spatial development and more. Concept of underdevelopment changes understanding on social formation transition, i.e. "a transition which is controlled by an articulation of two modes of production, capitalist mode of production and non-capitalist mode of production, and it depicts a more or will be more dominant capitalist presence over the other" Bellah, (1964). As the result, social formation in fringe area is marked by a set of dislocation among steps in social formation.

Process of spatial physical change in Metro Tanjung Bunga area during 2000-2003 has different characteristic compared to spatial physical development for 2003-2005. For 2003-2005, a symbol presenting capitalism is designated by presence of the biggest shopping center in Eastern Indonesia Zone (Mall GTC) driven by construction of Metro Tanjung Bunga road along with various kinds of activities. During 2006-2013, symbol representing capitalism is strengthened by presence of Theme Park Trans Studio that leads Metro Tanjung Bunga development to modernization and globalization. Based on the characteristics of developed activity, capital or investment will be fairly great in Metro Tanjung Bunga area. Significant land use conversion affects spatial physical change to the end of 2014. The overview above shows that land ownership structure in Metro Tanjung Bunga area are changing over times, and the land is dominantly utilized for large scale residential construction and commercial economic activity functions. Land ownership status change existing today gives an overview that there is a pressing force faced by local community with an indication of decreasing agricultural land and brackishwater pond and pressing tendency toward farmer over time. The reality is relevant with theoretical conceptualization of Yunus (2006) that fringe area development associates to pressing tendency toward farmer due to decreasing agricultural area. This condition depicts that spatial physical change in Metro Tanjung Bunga happens fast and revolutionary through process of penetration, and it is tailed by invasion and finally, the change dominates means of production, reproduction of space and succession that is entirely conducted by capitalism.

Early formation process of local community institution in Metro Tanjung Bunda was traditional agrarian community, and it was established based on values and norms known, comprehended, respected and obeyed by local community. This process is designated by the obeyed social values and norms, and they become principles the way to behave and to guide their life. Custom and tradition of local community concerning rituals have been such institutionalized and convinced that if something is not performed, member of or all people in society will be struck by bad luck. Traditions which are performed by local community in certain place/location, i.e. Jenneberang River Basin (Appanaung Parappo) are sacred with a purpose to begin an event and calamity preventive tradition. Both traditions are led by headman and organized in coastal area by buffalo slaughter ritual in purpose to prevent disaster and calamity that may threaten life of local community.

This process depicts that local community institution at ancient time was concerned with belief system held by and acquired by people hereditary from the ancestors and it is abode by local community. Based on classification of and type of community-based organization, institution has an important role to regulate attitude of local community, and it also becomes social capital in life of local community. There are some principles to assess local community institution existed at that time, they are (1) crescive institution is named as primary institution, it is an institution which is unintentionally established by local custom, (2) based on social acceptance, social sanctioned institution is an institution accepted by entire society, and (3) based on values system accepted by society, an institution is considered as basic institution.

Social formation grown up at that time was dominantly affected by orientation pattern to activity performed by local community and function of institution to preserve regulation in society. There were three social formations established by local community until the end of 1990, they are (1) subsistence peasant community; it is commonly established in Gontang, Lette, Malaka and Bayang villages, (2) fishing community; mostly, this community is in coastal area like Bayang and Angin Mamiri villages, and (3) local community with no arable land that makes people work as harbor porter. Any characteristics associated with social relationship pattern are brotherhood, mutual cooperation, and blood relationship. This condition is shown by dense social interaction pattern as an unified community. Life of local community in the ancient social formation was tied up by hereditary tradition. Tradition performed and abode by local community involves Songkobala tradition (to throw out bad luck/calamity that would befall). People believed that it affected local community life if the tradition were not conducted. Dato-Datoa tradition is performed in certain place (sacred location/site) around coastal area in which the offerings are made if people get abundant harvest.

The dynamic of social change in local community of Metro Tanjung Bunga area is indicated by scattered and fragmented pattern of society life. Fact found in the field depicts that some people in local community who had inhabited Metro Tanjung Bunga area prefer migration to standing still. They migrated to Takalar Regency to carry on their tradition as fisherman, while some other people moved to Gowa Regency as farmer. For those who still inhabiting the area, they stood still to live with the dynamic of new town development in Metro Tanjung Bunga. They were no longer relied on the job as farmer, but they change their orientation to non-formal activities like green vegetable peddler, construction worker, villa security guard in recreational site of Tanjung Bayam, handyman, domestic help, while a few of them work in formal sector in commercial/economic activity functions. Spatial useMetro tanjung Bunga describedin Table1. 
Table 1.Spatial Utilization in Metro Tanjung Bunga Area, 2006-2014

\begin{tabular}{|c|c|c|c|}
\hline No. & Spatial Utilization & Area Size (Ha) & $\%$ \\
\hline 1 & Field & 1.10 & 0.09 \\
\hline 2 & Brackishwater pond & 0.11 & 0.01 \\
\hline 3 & Profision Plan of Open Green Space & 52.58 & 4.37 \\
\hline 4 & Akkarena Recreation/Tourist Area & 14.32 & 1.19 \\
\hline 5 & Shopping Center (Somba Opu dan Rukan Gajah Mada Shophouses) & 2.86 & 0.24 \\
\hline 6 & Shopping Center (Mall GTC) \& Development Plan & 15,00 & 1.25 \\
\hline 7 & Education (Dian Harapan School) & 3.80 & 0.32 \\
\hline 8 & Health (Siloam Gleneagles Hospital) & 1.50 & 0.12 \\
\hline 9 & Office of PT. GMTD Tbk & 1.16 & 0.10 \\
\hline 10 & Recreational Facilities (Trans Studio) \& Development Plant & 24.00 & 2.00 \\
\hline 11 & Meeting Hall (Celebes Convention Center) & 1.50 & 0.12 \\
\hline 12 & Former Residential Area & 19.35 & 1.61 \\
\hline \multirow{17}{*}{13} & \multicolumn{3}{|l|}{ New Residential Area (established by developer) } \\
\hline & a. Toraja Park & 14.22 & 1.18 \\
\hline & b. Masamba Park & 6.89 & 0.57 \\
\hline & c. Losari Park & 5.19 & 0.43 \\
\hline & d. Khayangan Park & 10.35 & 0.86 \\
\hline & e. Residen R. Park 2000 & 1.25 & 0.10 \\
\hline & f. Mediteranian Park & 4.44 & 0.37 \\
\hline & g. Metropolitan Park & 3.12 & 0.26 \\
\hline & h. Grand Garden Park & 2.13 & 0.18 \\
\hline & i. Samalona Park & 4.81 & 0.40 \\
\hline & j. $\quad$ Losari 2000 & 7.52 & 0.63 \\
\hline & k. Ekspana Garden & 5.69 & 0.47 \\
\hline & I. Grand Garden & 9.08 & 0.75 \\
\hline & m. Osaka Garden & 1.36 & 0.11 \\
\hline & n. Menteng Garden & 6.72 & 0.56 \\
\hline & o. Danau Biru Vila & 15.14 & 1.26 \\
\hline & p. Pantai Biru Vila & 3.48 & 0.29 \\
\hline 14 & Gas Station & 0.30 & 0.02 \\
\hline 15 & Site Preparation for Raya Tanjung Bunda Mosque & 0.63 & 0.05 \\
\hline 16 & Site Preparation for New Residential Area & 505.80 & 42.06 \\
\hline 17 & Residential Area Land Development & 457.25 & 38.02 \\
\hline & & $1,202.22$ & 100.00 \\
\hline
\end{tabular}




\section{Social Change and Social Capital Difference in the Dynamic of New Town Develompent in Metro Tanjung Bunga Area}

Technological, transportation and communication network progresses obviously affect social relationship pattern of among communities in Metro Tanjung Bunga along with their cultural values and ethics after significant spatial physical change. The reality is relevant with theoretical conceptualization of Ibrahim (2005) that the importance of interpersonal relationship is an expression manifested from relationship all this time bound in community life in one unified residential environment. Further, Ibrahim (2005) suggests classical theory on typology of community which distinguishes types of simple and modern society. The theory is developed from society developmental stages in the West. Generally, sociability describes sense of togetherness as manifestation, sense of care in various activities, common discussion on ideas, participation in joint activity for formal or informal social organization. Sociability grows up and arises in society as social capital. Social capital as structure of interindividual relationship that allow people to create new values (Coleman, 1990). Further, Coleman suggests that social capital will be weakened by processes that may harm kinship relation like divorce or separation, or migration. It means that dynamic of new town development in Metro Tanjung Bunga from 2003 to 2014 has significant effect on social change as the consequence of function shift on spatial utilization. It also creates new values in local community due to acculturation process, especially acculturation between infiltrative migrants who make a choice to live among local community (Berger, 1984).

Surya, B., (2010), Meaning of social relationship/social relation developed by the presence of infiltrative migrants is designated by sense of care grown up in community. As a social potential developed in local community, it is used to preserve local community's existence in the changing environment condition. The reality affirms theoretical conceptualization of Fukuyama (1995) that social capital refers to "informal norms that support cooperation between interindividual and capability where the latter is established by prevalence of trust in a society or within certain parts of society. Accordingly, intercommunity social care in Metro Tanjung Bunga is commonly found in low stratum community where their housed is close by each other. Then, in expansive migrant, social capital tends to be weakened by life style differences. Accordingly, the current sense of care shall be improved since it is an indicator to assess intercommunity relationship pattern in Metro Tanjung Bunga, Makassar City (Harvey, D. 2009).

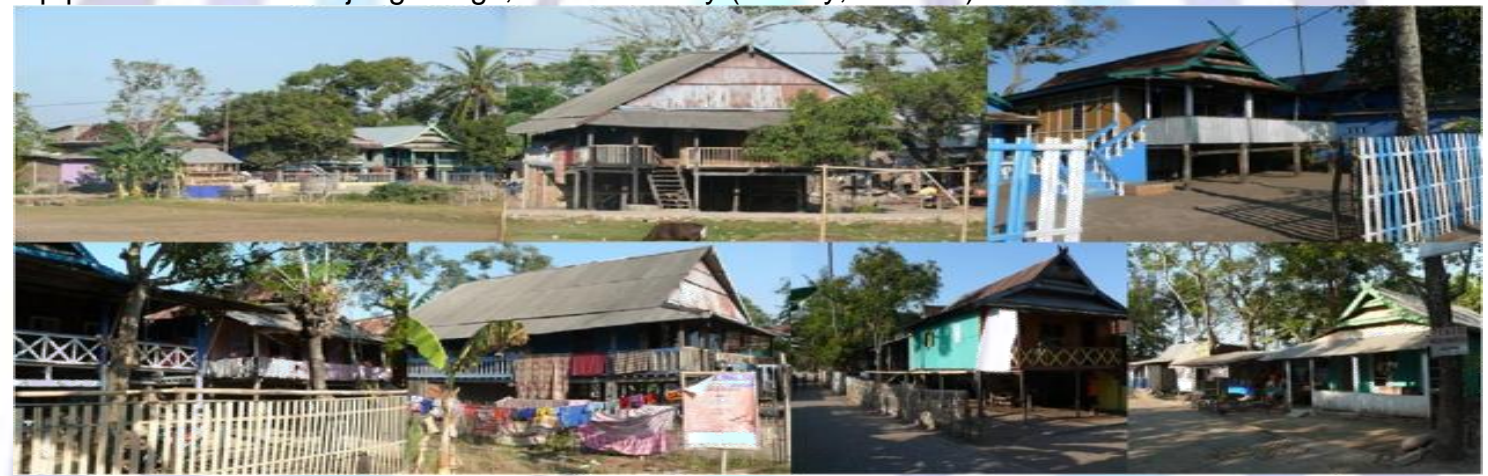

Fig 3.Local Community Residence Characteristics as the Means to Establish Social Interaction and Social Relations

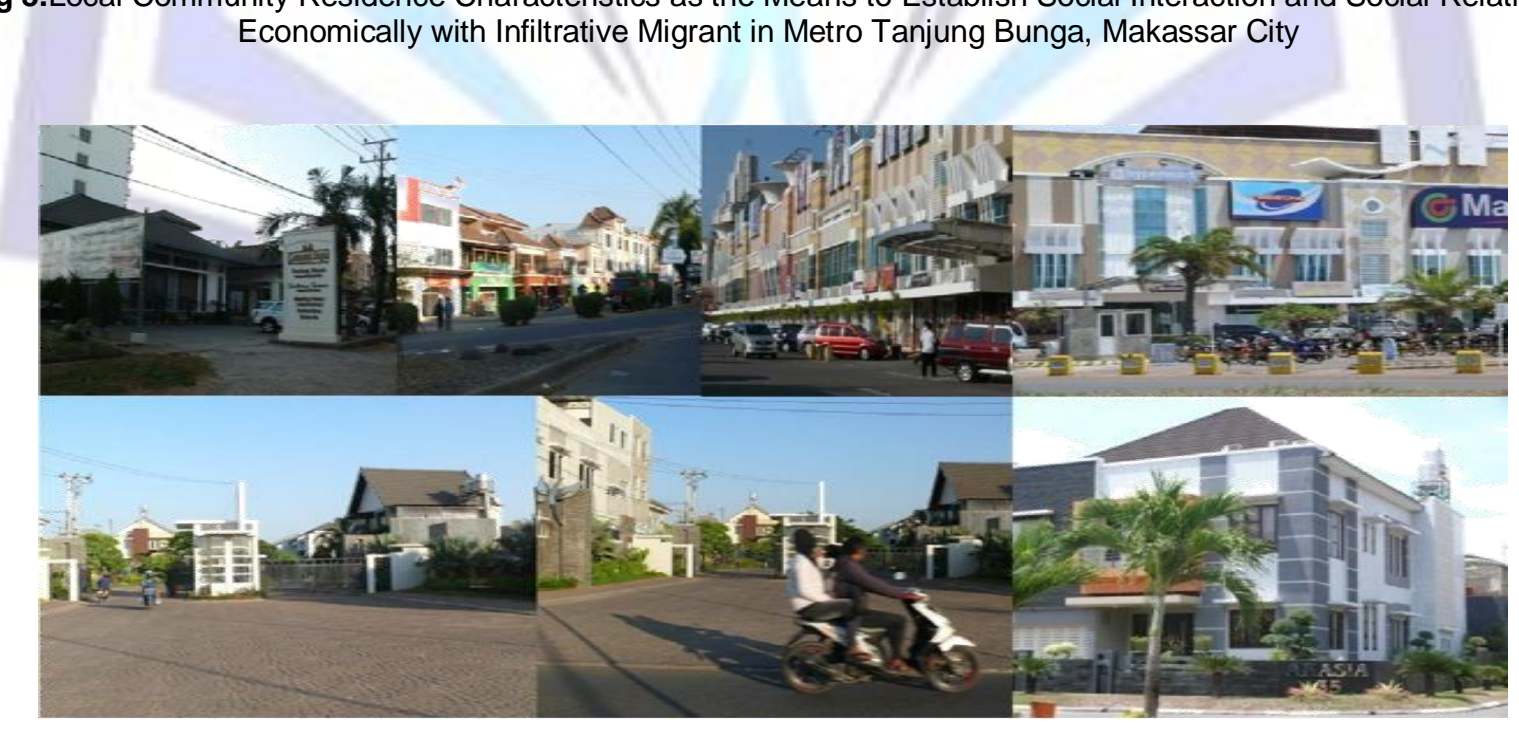

Fig 4.New Functions and Expansive Migrant Residence Characteristics as the Means of Social Interaction between Migrant and Local Community in Metro

Tanjung Bunga, Makassar City 


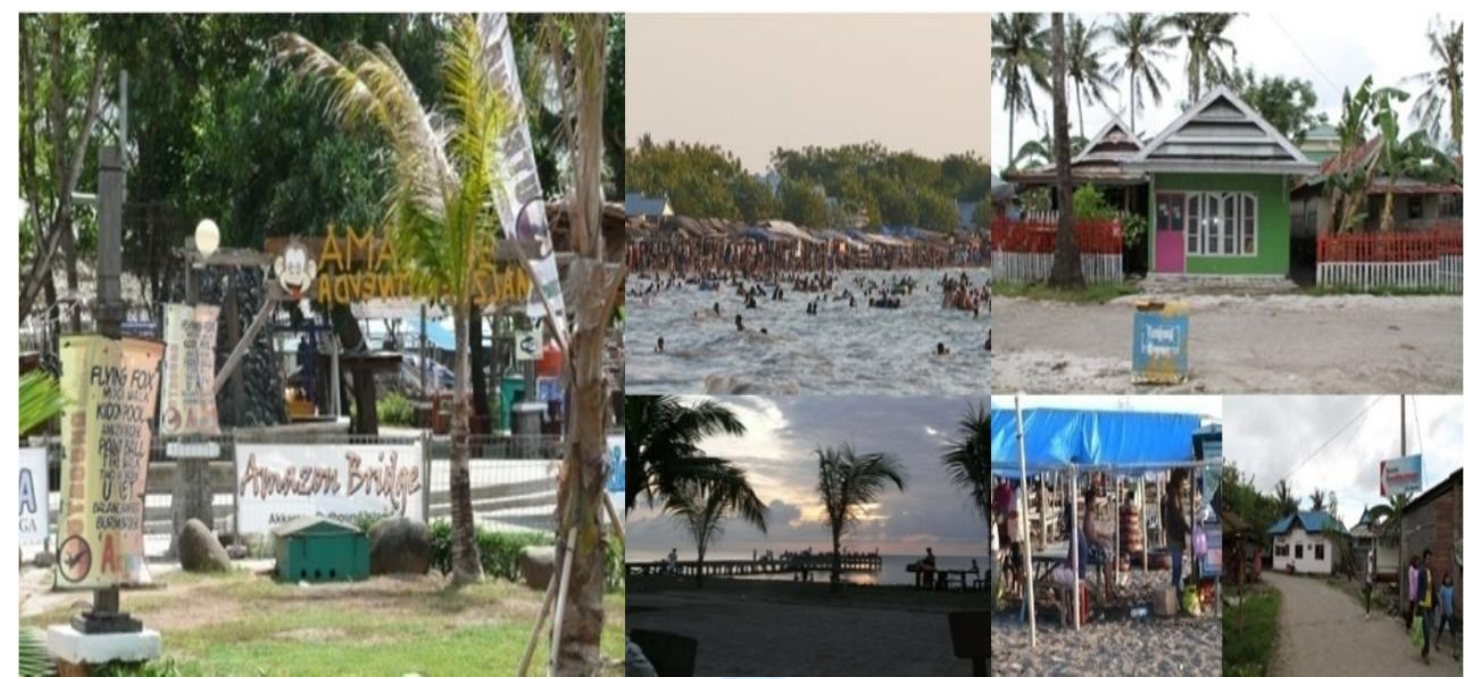

Fig 5.Recreational Facilities as the Medium of Social Interaction between Migrant and Local Community in Metro Tanjung Bunga Area.

In Figure3, 4, and5 above, based on common local community residence pattern integrated with infiltrative migrant in the new town of Metro Tanjung Bunga, local people are dominantly live in contiguous slum area and they do not have much furniture. Accordingly, the established social capital is highly affected by sense of acceptance performed by local community toward infiltrative migrant. Besides, both parties also establish mutual social relations regarding the existence of both communities in responding to and performing externalization to the new town accelerated development in Metro Tanjung Bunga area. The reality is relevant with theoretical conceptualization of Lawang (2004) that social capital refers to all community's social powers constructed by individual or group and referred to social structure. Based on their consideration, goals of individual and/or group are achievable effectively and efficiently if other capitals are combined.

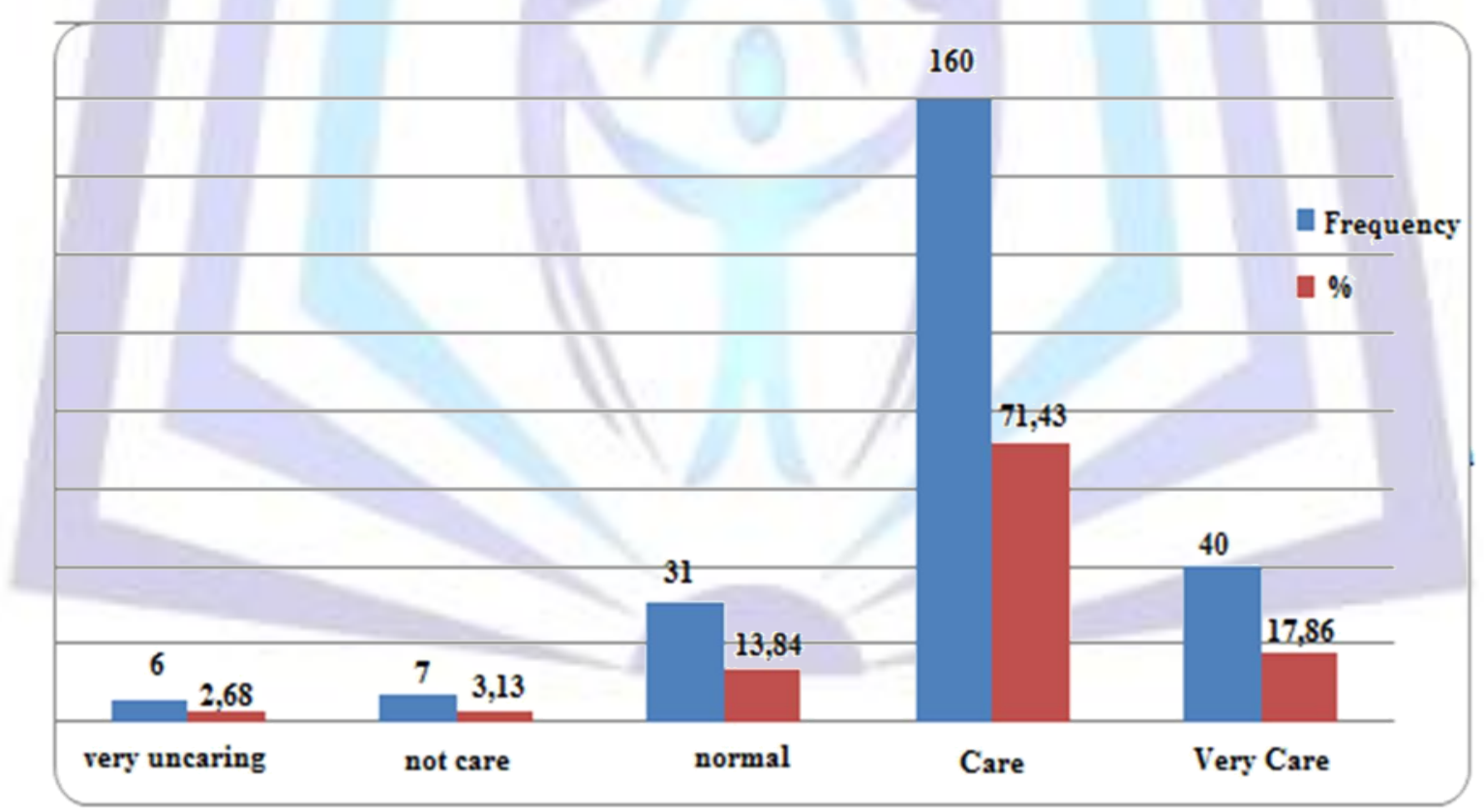

Fig 6.Intercitizen's Sense of Care between Local Community and Infiltrative Migrant in Metro Tanjung Bunga Area

Figure6aboveshows, as seen from the figure above, there are two interpretation proposal as follows: First, intercommunity's sense of care between infiltrative migrant and local community is high or $71.43 \%$. Accordingly, migrant arrival in infiltrative manner gets positive response from local community and residential environment to make this a chance in matching up interests among individuals from both communities. Second, construction of social order and development from a stable or permanent social relationship may grow up mutual trust among social actors. In simple society, trust will be melted into personal relationship pattern in community, kinship and friendship.

Social interaction between individual of local community are distinguished based on frequency of social interaction, they are: (1) social interaction that occurred in subsistence farming practice, (2) the social interaction taking place in kinship atmosphere in local community, and (3) reciprocal and mutual social interaction between individual from local community and individual from infiltrative migrant. 

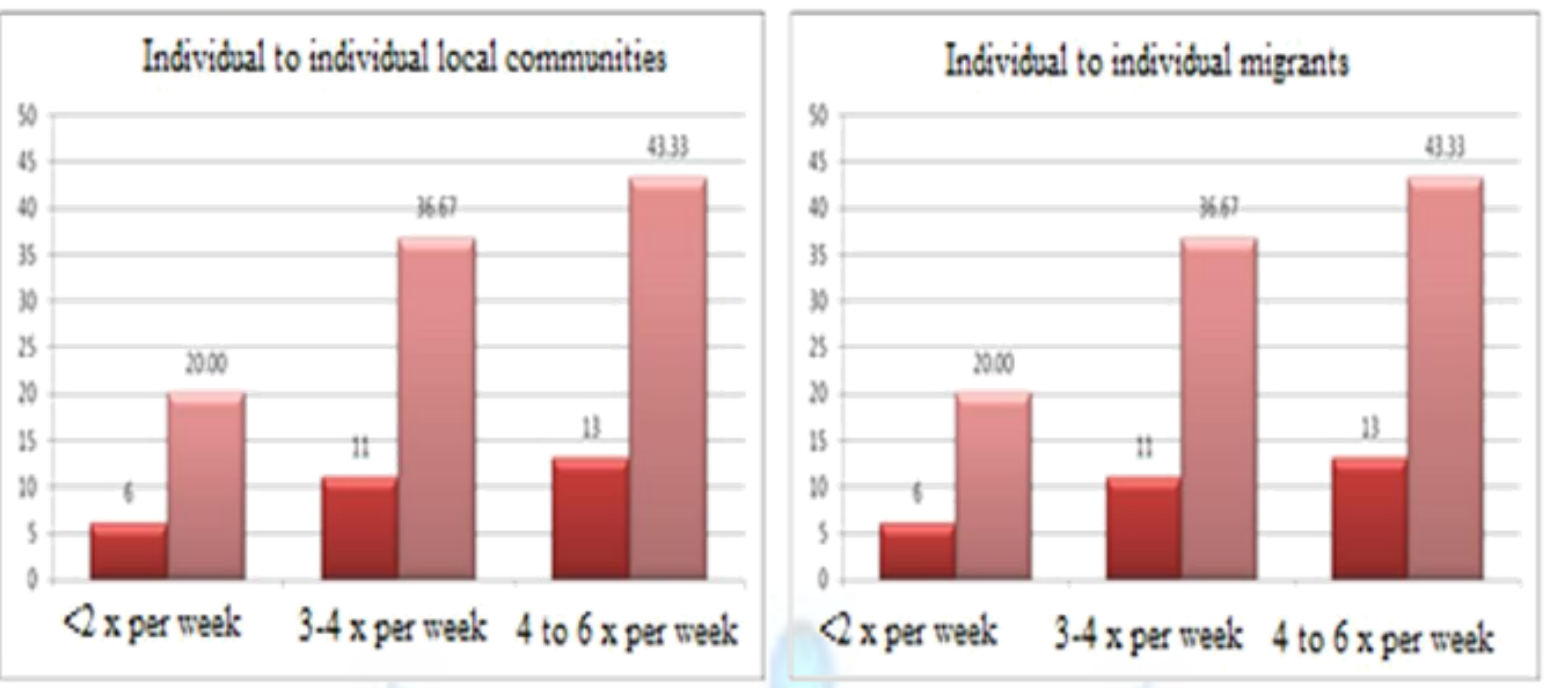

Fig 7. Social Interaction Intensity between Local Community and Infiltrative Migrant

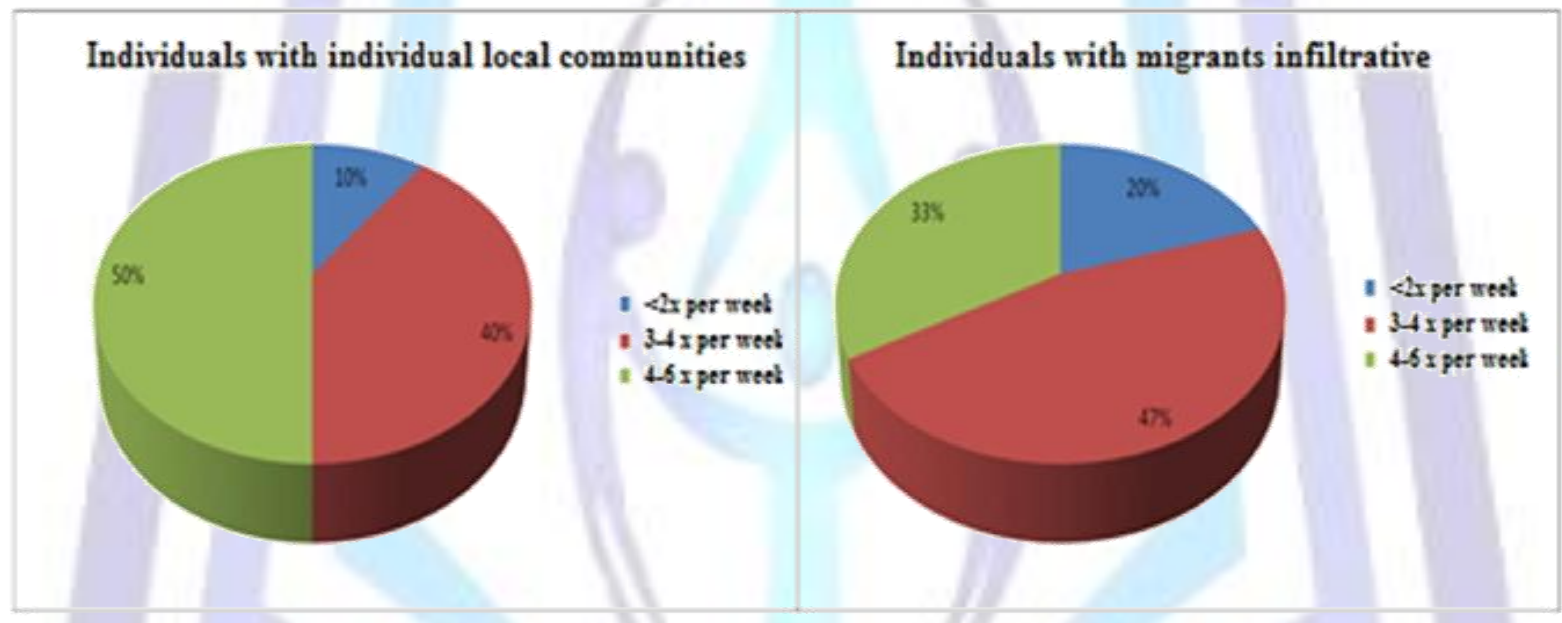

Fig 8. The Social Contact Taking Place between Local Community and Infiltrative Migrant in Metro Tanjung Bunga Area

As seen in the figure above, there are some revealable matters: (1) social contact may take place between individual and individual of local community intensively at frequency of 3 to 4 times per week or $40.00 \%$ or more at frequency of 4 to 6 per week or $50.00 \%$. Accordingly, the social contact is likely made by social life pattern in local community, (2) the social contact taking place between individual of local community and individual of infiltrative migrant has high intensity at frequency of 3 to 4 times per week or $46.67 \%$ and 4 to 6 times per week or $33.33 \%$. Accordingly, social contact performed by individual of local community and individual of infiltrative migrant is established on the basis of principle of togetherness in responding to environmental changes. The contact is also made in family atmosphere and economic motives.

Meaning revealed by the process of social interaction based on the occurred social contact indicates some things, they are (1) the social contact taking place between individuals of local community indicates the presence of family atmosphere bound by blood relationship based on lineage. It also shows the strength of tradition in local community as farmer on mutual principle between individuals of local community. (2) social interaction through social contact between local community and infiltrative migrant is work relation-based relationship in family atmosphere. Work relation, in this case, is work relationship pattern which is constructed between local community and infiltrative migrant. It is performed not only in work situation, but also daily life. Accordingly, social solidarity between communities is constructed positively.

The process of social interaction occurred in Metro Tanjung Bunda area after spatial physical change indicates differences on types of effort conducted by local community, and it highly depends on business or activity they do currently. 
Table 2.Comparison between the Processes of Social Interaction based on Orientation to Activity Conducted by Community in Metro Tanjung Bunga Area

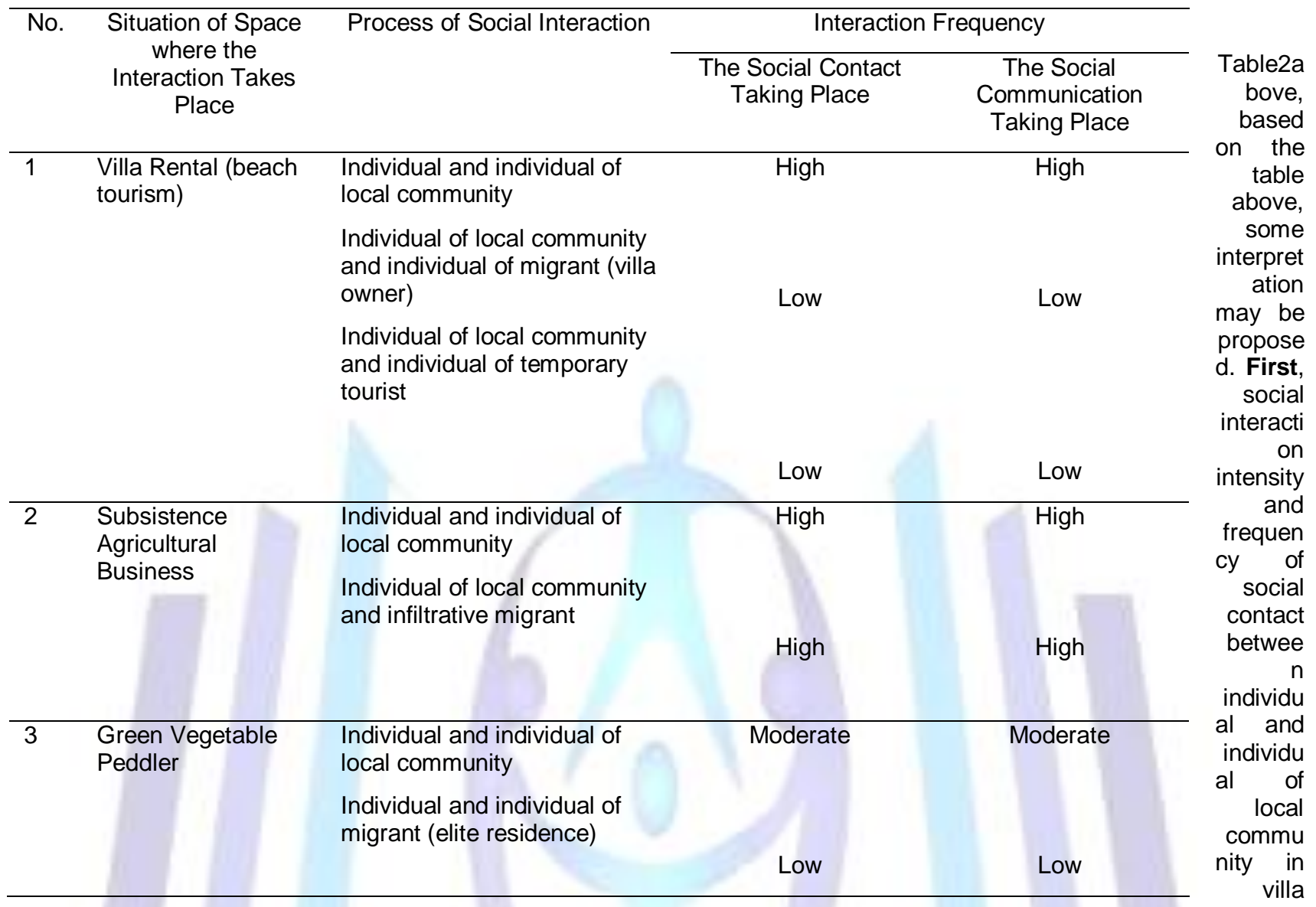

rental is high, social contact between individual of local community and migrant (villa owner) is low, and social contact between visitor and temporary migrant is also low. Accordingly, development of tourism activity is a media that allow individual's interests meet. Second, dominantly, villa are not possessed by individual of local community which can be utilized by individual of local community to meet migrant who possess the villa. When villa owner does not live in the same environment with local community, that social contact is chategorized as low. Third, social contact frequency between individual of local community and temporary migrant (visitor) is low, and it only occurs at particular situation and condition. Thus, process of social interaction is temporarily happened when it does not occur in daily life of local community. Frequency of social communication then is divided into three categories: (1) frequency of social communication taking place between individual and individual of local community is high, (2) frequency of social communication performed by individual of local community and individual of migrant as villa owner is low, and (3) frequency of social communication occurred between individual of local community and individual of temporary migrant is also low. Accordingly, condition existing today is affected by some things that: (a) local community lives within the same area, and lives together permanently, (2) migrant as villa owner does not live in the same area, but they have an authority over villa rental they possess; migrant and local community meet each other once to twice per week and mostly, they communicate via phone call, and (3) temporary migrant comes and lives in the area at anytime, any holiday season, toward the fasting month, feast day or at any occasional event for recreational activities in tourism resort; thus, villa is the medium for social communication.

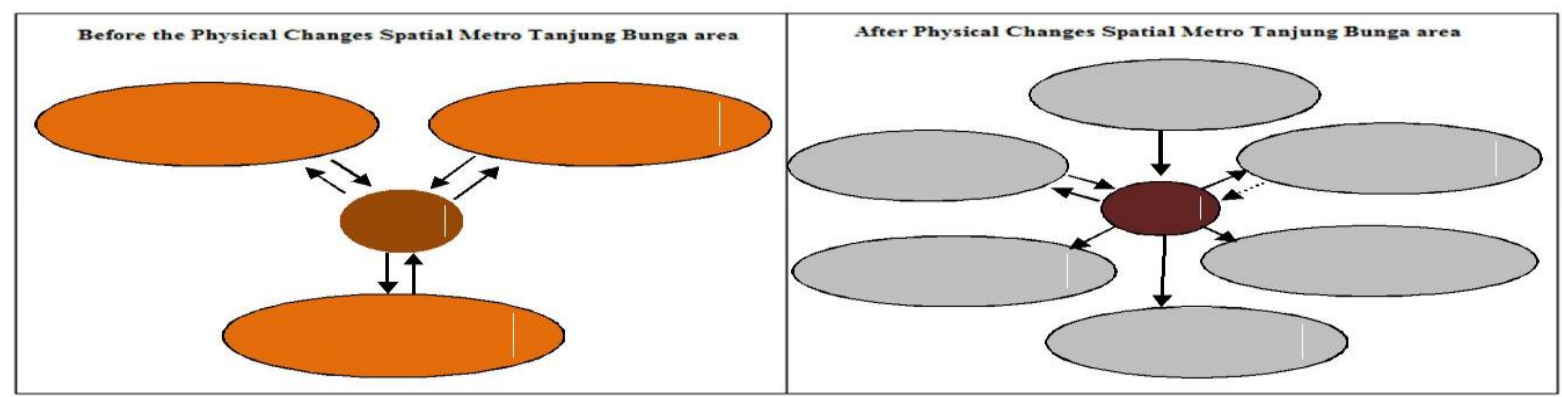

Fig 9.Sociometry of SD of the Local Community Having the Profession of Employee in Mall GTC in Capitalist Social Formation 
The figure above shows sociometric relationship of SD with his profession of employee in Mall GTC in capitalist social formation. Based on the Figure 2, some interpretation may be proposed. First, social interaction relationship between SD and nuclear family as the smallest social unit works intensively. This condition is affected not only by emotionally strong feelings, but also that family becomes the prime motives actuating SD to improve his family's prosperity where the media to achieve the goal is Mall GTC. Second, social relations between SD and fellow worker (employee of Mall GTC) in his interaction indicates high intensity, while Mall GTC is a medium to carry out the process of social interaction either in form of social contact or the way they establish fairly intensive and reciprocal communication. Third, the social interaction occurring with relatives is low. Accordingly, spatial physical change in Metro Tanjung Bunga affects significantly life of local community. Fourth, the social interaction taking place in local community, in this case is interaction between SD and community, is decreasing. This condition is indicated by current communication and social contact. Based on both frequencies, it is low and it tends to take place occasionally.

Fifth, social interaction between SD and mall visitor works intensively and reciprocally, and it has significant effect on the profession done by SD. Accordingly, the increasing number of visitor to Mall GTC will affect employee's prosperity. Sixth, social interaction between SD and management is one-way interaction, and it becomes a control over job performance. Accordingly, in capitalist social formation, the control over job performance which becomes an authority over employment process is designated by working class relationship in a system of capitalist means of production.

Interpretation of the changing orientation to activity performed by local community shows social fragmentation in life of local community. Accordingly, orientation difference in local community highly affect social relationship pattern and social relation changes in local community. One of the indications is shown by process of social interaction either between individuals, individual and group, or between groups in the new social formation.

Related to theoretical conceptualization of Meillasoux and Rey (1972), it can be concluded that coexistence of precapitalist social formation and capitalist social formation triggers social changes in local community, and this change is so affected by rapid and revolutionary spatial physical change. Dualistic penetration between capitalism and modernization in Metro Tanjung Bunga area triggers the development of formal and informal activities. This dualistic factors make process of social

\section{Social Capital of Urban Society in the Dynamic of Sustainable New Town Development}

Social capital is social resource which can be considered as an investment to obtain a new resource in society. Therefore, social capital is believed to be one of main components in actuating togetherness, ideas mobility, mutual trust, and mutual advantage for collective progress relating to the dynamic of new town development in Metro Tanjung Bunga. Fukuyama (1999) suggests that social capital has an essential role in functioning and strengthening life of modern society. Social capital is a requirement that shall be met for human development, economic, social, politic development, and democratic stability. Multiple problems and deviances faced by countries are mostly caused by the stuntedness of social capital growing up in the midst of society (Gidden, A. 2004). Thus, framework of the upcoming new town development is so important since it relates to making consideration and prediction on possible social change and social capital shift in society as the consequence of urban spatial function shift, especially in the fringe area. When any interest of groups meet each other in the mastery of reproduction of urban space at revolutionary changes, the existence of local community since the beginning of their occupation in the fringe area does not face any fragmentation in the dynamic of spatial utilization shift if all interests they have are accommodated. Therefore, social cohesion in the new town development will create continuance socially, physically and economically (Gidden, A. 2008;

Gidden, A. 2005; Granovetter, M., 1985; Grootaert, Christian. 1998; Hans-Dieter Evers and Rudiger Korff, 2000; Hariyono.P (2007).

\section{Conclusion}

Functions shift of major activity in Makassar City heading to the fringe area of Metro Tanjung Bunga through the development of a new town area will lead to a very significant land use conversion, and land use conversion becomes the driving force for the process of urbanization. As the result, urbanization is designated by the coming of infiltrative and expansive migrant.This process then causes spatial articulation which is indicated by coexistence of capitalist mode of production and pre-capitalist mode of production where the two modes of production depicts dominance over mastery of reproduction of space by capitalism. Consequently, it causes social change in local community.

Social change in local community is designated by social interaction change and social adaptation. The process of social interaction taking place has different characteristics and types. Social interaction between individuals of local community has a tendency in growing up social relations in kinship relation. Social interaction between local community and infiltrative migrant has symbiosis of mutualism by making work relations economically in a framework to make existence of local community run along environmental change. Further, social interaction between local community and expansive migrant tends to be employer-employee-based relationship which is shown by working classes relation in capitalist social formation. Difference of the process of social interaction then creates differences of the social capital developing in the dynamic of new town of Metro Tanjung Bunga, Makassar City.

The differences of social capital emerging in the dynamic of new town development in Metro Tanjung Bunga is determined by differences of each society's characteristics in establishing collective social solidarity. In local community and infiltrative migrant, the established social capital is highly affected by sense of acceptance performed by local community toward 
infiltrative migrant. Besides, both parties also establish mutual social relations regarding the existence of both communities in responding to and performing externalization to the accelerated development in Metro Tanjung Bunga area. The social capital developed between local community and expansive migrant only takes place at particular situation and condition heading toward control over job performance and authority over employment process. Indication of this phenomenon is shown by working classes relationship in capitalist means of production and production system.

\section{Referensi}

[1] Borja Jordi \& Castells Manuael (1977), Local \& Global: Management of Cities in The Information Age, London: Eartscan Publication Ltd.

[2] Berger, Peter L, 1984. capitalistrevolution. Jakarta. Penerbit LP3ES.

[3] Bellah, Robert N. 1964. "Religious Evolution." HIm 74-358 in American Sociologi Review, Vol. 29.

[4] Coleman. J., 1990. Foundations of Social theory. Cambridge Mess: Harvard University Press.

[5] Coleman, S. J. 2008. Dasar - Dasar Teori Sosial. Penerbit. Nusa Media.

[6] Castel, Manuel. 1990. Global Restructuration and Territorial Development, Blackwell.

[7] Cresswell, J W. 1997. Resech Design Qualitative and Quantitative Aproach. London: Sage Publication.

[8] Durkheim, Imile. 1986. Durkheim dan Pengantar Sosiologi Moralitas. Disunting oleh Tafik Abdullah dan A.C. van der Leeden. Penerbit. Yayasan Obor Indonesia.

[9] Fukuyama, F. 2005. Guncangan Besar: Kodrat Manusia dan Tata Sosial Baru (terjemahan oleh : Masri Maris. Judul asli : The Great Disruption: Human Nature and the Recostitusion of Social Order) Penerbit. PT. Gramedia Pustaka Utama

[10] Fukuyama Francis. 1995. Trust : The social Virtues and the Creation of prosperity. New York. Free Press.

[11] Fukuyama, Francis. 1999. The End of History and The last Man :Kemenangan Kapitalisme dan Demokrasi Liberal, Yogyakarta : Penerbit Qalam.

[12] Gidden, A. 2004. Sosiologi : Sejarah dan Pemikirannya (terjemahan oleh: Ninik Rochaini Sjam. Judul asli : La Sosiologie: Hirtorie at Idees) Penerbit. Kreasi Wacana.

[13] Gidden, A. 2008. Social Theory Today : Panduan Sistematis Tradisi dan Tren Terdepan Teori Sosial. Penerbit. Pustaka Pelajar

[14] Gidden, A. 2005. Konsekuensi-Konsekuensi Modernitas. (terjemahan oleh : Nurhadi. Judul asli : The Consequences of Modernity) Penerbit. Kreasi Wacana.

[15] Granovetter, M., 1985. "Economic Action and Social structure: the Problem of Embeddedness. "American Journal of sociology".

[16] Grootaert , Christian. 1998, Social Capital :The Missing Link?, The Work Bank Social

[17] Hans-Dieter Evers and Rudiger Korff (2000), South Asian Urbanism, Them Meaning and Power of Social Space, Germany: Lit Verlag.

[18] Hariyono.P (2007), Sosiologi Kota Untuk Arsitek. Penerbit Bumi Aksara,Jakarta.

[19] Harison, E. L. Huntington, S.P. 2006. Kebangkitan Peran Budaya : Bagaimana Nilai - Nilai Membentuk Kemajuan Manusia (terjemahan oleh : Retnowati, Judul asli : Culture Matters : How Values Shape Human Progres) Penerbit. LP3ES Indonesia.

[20] Harvey, D. 2009. Neoliberalisme Dan Restorasi Kelas Kapitalis. Penerbit. Resist Book.

[21] John Eade (1997), Living the Global City, Globalization as Local Process. London: Sage Publication.

[22] Levi, 1998. Trust and Governance, New York : Russell Sage Foundation Limited.

[23] Linda D. Ibrahim. 2002. Kehidupan Berorganisasi sebagai Modal Sosial Komunitas Ketetanggaan di Jakarta.Penerbit. URDI

[24] Lee, L. 1979. Factors Affecting Land Use Change in the Rural-Urban Fringe in Grow and Change: A Journal of Regional Development, 10.

[25] Lefebvre, H. 1981. La Produktion de L'espace. Edition Anthoropos.

[25] Lefebvre, H. 1996. Writing on Cities,. Blackwell Publisher.

[26] Michael Peter Smith (1980), The City and The Social Theory, Oxford: Basil Blackwell.

[27] McGee, T.G. 1997. The Emergence of Desa-Kota Region in Asia: Expanding a Hypothesis, in Notton Ginsburg, Bruce Koppel, T.G. McGee (eds). The Extended Mtropolis and Setlement Transition in Asia. Honolulu: The University of Hawail Fress. 
[28] McGee, T.G. 1971. The Urbanisation Procces in the Third World. Bell, London

[29] Millassoux, C. 1972. From Reproduction to Production. Economic and Society.

[30] Suseno, F.M. 2005. Pemikiran Karl Marx: Dari Sosialisme Utopis ke Perselisihan Revisionisme. Penerbit. PT. Gramedia Pustaka Utama.

[31] Soetomo, S. 2009. Urbanisasi Dan Morfologi : Proses Perkembangan Peradaban dan Wajah Ruang Fisiknya. Penerbit. Graha Ilmu Yogyakarta.

[32] Surya, B., (2010). Perubahan Sosial Pada Komunitas Lokal Kawasan Metro Tanjung Bunga Kota Makassar, Laporan Hasil Penelitian Disertasi, tidak terpublikasi. Program Pasca Sarjana UNM.

[33] Yunus, S.H. 2006. Megapolitan: Konsep, Problematika dan Prospek. Penerbit Pustaka Pelajar.

[34] Yunus, S.H. 2008. Dinamika Wilayah Peri-Urban Diterminan Masa Depan Kota. Penerbit. Pustaka Pelajar. 